\title{
Open economy politics: A critical review
}

\author{
David A. Lake
}

Received: 26 January 2009 /Revised: 23 March 2009 /Accepted: 5 May 2009 /

Published online: 28 May 2009

(C) The Author(s) 2009. This article is published with open access at Springerlink.com

\begin{abstract}
An emergent paradigm, referred to as Open Economy Politics (OEP), now structures and guides research among many scholars. This essay sketches the general contours of the paradigm. Scientific accumulation is, in my view, the potential and great benefit of a self-conscious understanding of OEP as a single, unifying paradigm. The essay also provides a sympathetic critique of OEP and shows how the paradigm can be extended to capture some of the concerns and insights of other critics. Most important, this critique highlights the role and consequences of certain simplifying assumptions commonly used in OEP and calls for a closer examination of how international institutions and policies structure and change the interests of actors within countries that are now taken as exogenous.
\end{abstract}

Keywords Political economy · Globalization · Institutions · Bargaining · Optimal tariffs · Economies of scale

JEL Codes $\mathrm{F} 02 \cdot \mathrm{F} 13 \cdot \mathrm{F} 50 \cdot \mathrm{F} 59$

\section{Introduction}

The world has become "globalized." Among developed countries, international trade now accounts for approximately $40 \%$ of gross domestic product (GDP), and for developing countries imports plus exports comprise nearly $50 \%$ of all national output. Over the last two decades, global flows of foreign direct investment have more than doubled relative to GDP. The financial crisis that began in the United States in September 2008 quickly became a global crisis, essentially plunging Iceland into bankruptcy within days. As journalist Thomas Friedman $(2000,9)$ has famously described it, globalization now allows "individuals, corporations, and

D. A. Lake $(\bowtie)$

Department of Political Science, University of California, San Diego, La Jolla, CA 92093-0521, USA

e-mail: dlake@ucsd.edu 
nation-states to reach around the world farther, faster, deeper and cheaper than ever before."

The field of international political economy (IPE) was created in the early 1970s by scholars trying to grasp the fundamentals of this nascent age. From a range of early perspectives, an emergent paradigm, referred to as Open Economy Politics (OEP), now structures and guides research among many scholars. ${ }^{1}$ Yet, although OEP is widely practiced, it has not been synthesized or, even less, codified as a coherent research program. Some scholars may not recognize that they are part of this emerging paradigm even though their research is central to it. One purpose of this essay is to sketch the general contours of the paradigm and to suggest how different streams of research are actually complementary and, in fact, contribute to a single, more powerful scholarly river. By understanding the contours of the emergent paradigm, it is easier to connect pieces of research and, in turn, to build cumulative knowledge. OEP helps identify what we know, what we think we know, and what we do not know. Scientific accumulation is, in my view, the potential and great benefit of a self-conscious understanding of OEP as a single, unifying paradigm.

All paradigms, however, privilege certain assumptions, methods, and epistemologies over others. This is the inevitable and unavoidable cost of greater accumulation made possible by those same assumptions, methods, and epistemologies. Some fear the "intellectual mono-culture" that any paradigm implies; better to have many competing and usually incommensurate approaches, in this view, than to pick the wrong (or perhaps any) paradigm. ${ }^{2}$ A second purpose of this essay is to provide a sympathetic critique of OEP and show how the paradigm as it is now emerging can be extended to capture some of the concerns and insights of other approaches. Although now conceived in somewhat narrow terms, OEP is broader and potentially more flexible than some of its proponents and certainly its critics imply.

As is no doubt already evident, I am of "two minds" in this essay. ${ }^{3}$ At the same time as I seek to describe the emergent paradigm of OEP, I also aim to extend and enlarge it in useful ways. ${ }^{4}$ To the extent that my critique is persuasive, proponents may well charge that I described the paradigm too narrowly in the first place. In turn, more strident critics may well retort that any such extensions only show that OEP is not and perhaps should not be accepted as a paradigm. Accepting that the task is difficult and likely to prove unsatisfactory to many, I nonetheless try to walk the fine line between these two positions.

\footnotetext{
${ }^{1}$ I use the concept paradigm here in the sense of Kuhn (1970), not in the looser sense normally used in political science as a school of thought. Indeed, in Kuhn's view, the existence of many competing schools is prima facie evidence of a pre-scientific or non-paradigmatic research program. The term OEP comes from Bates (1997).

${ }^{2}$ The phrase is from McNamara (2009). For defenses of intellectual pluralism, see the debate over the Atlantic divide in IPE, and especially Cohen (2007), Phillips (2009), Wade (2009), and Katzenstein (2009).

${ }^{3}$ On the "two minds" problem in IPE, see Weaver (2009).

${ }^{4}$ Although I have been accused of being a "triumphalist" advocate of OEP (Cohen 2009, 140), my own research does not fall neatly into the paradigm as it now exists. Indeed, this outsider's stance motivates much of my critique of OEP in the final section of this essay. I do, however, prize scientific accumulation and work within the broader strategic choice approach of which OEP is a subset. See Lake and Powell (1999). For an attempt to outline this strategic choice approach at a general level, see Frieden et al. (2009).
} 
IPE and specifically OEP have been intimately linked with the study of international organizations, the focus of this journal. Some of the earliest theoretical work on international regimes focused on the world economy, where intuition suggested that such institutions were likely to be particularly consequential (Krasner 1983; Keohane 1984). As the study of international institutions has matured, the field has attempted to move beyond IPE and become a more general theory, with successful applications to the environment, human rights, and even security. At the same time, however, the field has narrowed its purview to how and when institutions "matter" and is increasingly focused on the rules of particular institutions. OEP reminds scholars that even international institutions are but one part of a broader political process, and that their role and effects can be fully understood only in that context. A third purpose of this essay, then, is to suggest that OEP provides a model of how international institutions can be studied and understood from within an integrated theoretical approach.

This article provides an overview of IPE theory with particular attention to the role of international institutions. It begins with a brief outline of the early origins of the field, and then provides a survey of OEP. In Section 4, I offer a sympathetic critique of the emergent paradigm that aims to integrate concerns of some critics and identify the agenda for future research. Most important, this critique highlights the role and consequences of certain simplifying assumptions commonly used in OEP and calls for a closer examination of how international institutions and policies structure and change the interests of actors within countries that are now taken as exogenous. By relaxing these peripheral assumptions within OEP, I show how the emergent paradigm can address at least some of the criticisms raised by less sympathetic commentators.

\section{International Political Economy}

IPE focuses on the politics of international economic exchange. It is a substantive area of inquiry, rather than merely a methodology in which economic models are applied to political phenomena. The field is primarily informed by two sets of key questions. First, how, when, and why do countries choose to open themselves to transborder flows of goods and services, capital, and people? In other words, what are the political determinants of what we now call globalization? In this first set of questions, openness is the dependent variable, or outcome to be explained, and politics (defined broadly) is the independent or causal variable. Economic theory posits that free and unrestricted international commerce is, with limited exceptions, welfare improving; many politically naïve analysts, in turn, expect countries to evolve toward free trade. By contrast, IPE begins with the reality that openness is historically rare, problematic, and a phenomenon that itself needs to be explained. Second, how does integration (or not) into the international economy affect the interests of individuals, sectors, factors of production, or countries and, in turn, national policies? Here, politics is the dependent variable and how the actor is situated in the international economy is the independent variable. In reality, of course, these two sets of questions are themselves integrated. For pragmatic purposes, however, nearly all analysts study just one half of the causal circle. 


\subsection{Origins}

Although these questions were central to political economists of the late 18th and early 19th centuries, they fell into an intellectual limbo with the split between economics and political science into two separate disciplines in the late 19th century. ${ }^{5}$ As economics underwent the "marginalist" revolution and slowly transformed itself into an axiomatic science and political science turned to the study of formal-legal constitutions and institutions, both disciplines grew increasingly introspective. Questions concerning the political foundations of markets and the economics of politics were left to languish - or were happily consigned to Marxists who were largely ostracized from both professional disciplines in Europe and North America. ${ }^{6}$

IPE emerged as a new and distinct interdisciplinary field beginning in the late1960s and early-1970s as a result of two real world developments. ${ }^{7}$ Together, these trends forced scholars to grapple anew with the same questions that had occupied earlier political economists. First, the success of the postwar Western international economic regime constructed at Bretton Woods and embodied in the postwar institutions of the International Monetary Fund, World Bank, and General Agreements on Tariffs and Trade (GATT), ushered in an era of increasing economic interdependence. By the end of the 1960s, as the tariff cuts negotiated at the Kennedy Round of the GATT took full effect, trade as a proportion of economic activity began to rise rapidly in all advanced industrialized democracies, leading to a new focus on the political impact of deepening economic ties (Cooper 1968; Keohane and Nye 1972). This new era was expected by some to transform the nature of international politics, with economic historian Charles Kindleberger $(1969,207)$ famously proclaiming that "the nation-state is just about through as an economic unit" and political scientists Robert Keohane and Joseph Nye (1977) unveiling a new model of international politics characterized by "complex interdependence" and international regimes. We now recognize this surge of interdependence as the first stirrings of the present era of globalization, more frequently dated from the removal of capital controls in many developed economies in the early 1980s. Many today still believe that globalization carries the same transformative potential.

Second, at nearly the same time that interdependence was accelerating, the political foundations of this open international economy began to crack, revealing for all that economic exchange rested on unstable political ground. In August 1971, facing the huge dollar "overhang" first theorized by economist Robert Triffin (1960) and the consequences of a decade of fiscal and monetary mismanagement, President Richard Nixon formally ended the convertibility of the dollar into gold, closing the door on the Bretton Woods regime (Gowa 1983). Two years later, the postwar exchange rate regime collapsed when the major currencies began to float against one another. Contributing to this monetary instability, the Arab boycott begun during the

\footnotetext{
${ }^{5}$ For an analysis of the early years of political economy and its trajectory, see Caporaso and Levine (1992).

${ }^{6}$ The hostility to Marxism at least in the United States continued to inhibit the growth of IPE into the 1970s. Gourevitch (1977) was originally rejected by a leading journal of international relations as "Marxist claptrap." Personal communication.

${ }^{7}$ For an extended treatment of the origins of IPE, see Cohen (2008).
} 
1973 Middle East war transformed oil into a coercive weapon. Breathing life into the Organization of Petroleum Exporting Countries (OPEC), first formed in 1960, the factious states began to operate effectively as a cartel, raising oil prices fifteen fold between 1973 and 1980. Envying OPEC's success, even while suffering under higher oil prices, the developing world called for a New International Economic Order through which other commodity producers hoped to exercise similar market power with the acquiescence or hopefully support of Northern consumers (see Krasner 1985). Finally, in response to the growth of imports unleashed by liberalization and rising interdependence, American industry began clamoring for increased or renewed trade protection. Trying to satisfy industry without undermining its commitment to free trade, the United States adopted a series of innovative non-tariff barriers to trade including "voluntary export restraints," directed primarily at Japan (Goldstein 1988). As international economic relations were politicized, it became apparent that international exchange was not an autonomous sphere-a natural phenomenon beyond political machinations - but was itself a product of the pulling and hauling of politics within and between countries. Just as property rights later came to be understood as both central to economic growth and a product of redistributive politics within countries, early international political economists realized that an open international economy rested on highly contested national policy decisions (Gilpin 1972). As analysts struggled to understand the simultaneous growth and conflict in international markets, the field of IPE was born.

There were three main strains of theory in the initial blossoming of IPE. ${ }^{8}$ Dependency theory, founded by Latin American scholars writing in the 1960s and popular in North America and Europe in the 1970s, was unified by the idea that the economy and prospects for development in poor countries (the periphery) are conditioned by a global economy dominated by already developed states (the core). ${ }^{9}$ In the view of Andre Gunder Frank (1966), one of the more strident advocates of the approach, today's poor countries are not just undeveloped, as had been the case for core countries centuries earlier, but are underdeveloped by an international economy that is forever biased against them. Dependency theory tapped into issues of international inequality, uneven growth, and national control over international economic forces that remain central to contemporary debates about globalization. Even if today dependency theory is broadly rejected, the real world concerns that lent it credence endure.

Hegemonic stability theory, based largely on the experiences of Great Britain in the mid-19th and the United States in the mid-20th centuries, posited that a single hegemonic state is necessary and sufficient for international economic openness to arise. ${ }^{10}$ Kindleberger $(1973,305)$ first identified a series of what we would now call international market failures that caused the Great Depression of the 1930s, and concluded "that for the world economy to be stabilized, there has to be a stabilizer, one stabilizer." Others in this approach posited that large dominant states possess strong preferences for free and open international exchange and, in turn, coerce,

\footnotetext{
${ }^{8}$ An alternative typology divides theories into Marxist, Liberal, and Realist approaches. See Gilpin (1975).

9 The cornerstone of dependency theory is (Cardoso and Faletto 1979), first published in Spanish in 1967. An early approach was Prebisch (1964). See also Marini (1972), Furtado (1973), and Sunkel (1969).

10 The theory is reviewed in greater detail in Lake (1993).
} 
induce, or persuade other states into opening their markets to foreign trade and investment (Gilpin 1975, 1977; Krasner 1976). Although plausible, these alternative intuitions did not produce a body of well-specified theory. Nonetheless, hegemonic stability theory called attention to the role of great powers and political power more generally in determining the nature and extent of globalization.

A final early approach to IPE focused on domestic interests, largely in the advanced industrialized economies and, especially, the United States. ${ }^{11}$ Practical observers of politics and, of course, scholars as early as E. E. Schattschneider (1935) had emphasized the importance of interest groups in trade policy. Yet, domestic theories of international political economy emerged only in the mid-1970s. An early foundation was Kindleberger's (1951) essay on Group Behavior and International Trade, followed by, in political science, Peter Gourevitch's (1977) study of the first great depression and, in economics, Richard Caves' (1976) evocative rendering of different models of trade policy-making. ${ }^{12}$ Key to much of this work was the differential ability of actors to solve their collective action problems and then build majority coalitions with, ultimately, importers triumphing politically over exporters, producers over consumers, and concentrated over diffuse interests. Less important than how groups define their interests (see below) was how they are structured and organized for political action.

Although each was promising, these early approaches did not cumulate in any meaningful sense. They adopted different units of analysis: classes, nation-states, and sectors, respectively. They posited different interests - class struggle, national interests, and economic well-being - that could not be aggregated or disaggregated one into the other; national interests, for example, were not simply the sum of the economic interests of a country's sectors, or vice versa. ${ }^{13}$ In turn, they produced very different sorts of explanations. Although hegemonic stability theory appeared to comport with the evolution of national trade policies over time and the general pattern of openness or closure in the international economy, for instance, it was silent on tariff rates across sectors at any moment in time, and even as the domestic interests approach explained the latter, it was largely unable to explain the former. While there was lots of theoretical ferment - these were, indeed, intellectually heady years (see Keohane 2009) — there was little accumulation of knowledge across the field.

\section{Open Economy Politics}

Out of these early currents, and as a direct descendent of the domestic interests approach, OEP emerged as a nascent paradigm of IPE by the late 1990s. OEP adopts

\footnotetext{
${ }^{11}$ Complementing this domestic interest group approach, at least in political science, is a domestic structures model that seeks to characterize and capture institutional variations across developed countries (Katzenstein 1978; Ikenberry et al. 1988).

${ }^{12}$ In the ferment of the early years of IPE, political scientists built on these works to construct a demandside or societal-based theory of trade policy (McKeown 1984; Cassing et al. 1986; Frieden 1988b; Milner 1988). At about this same time, economists developed a parallel "endogenous tariff theory" which also emphasizes the importance of domestic interests and lobbying (Pincus 1975; Lavergne 1983; Baldwin 1985; Magee et al. 1989).

${ }^{13}$ For an important statement of this problem, see Krasner (1978).
} 
the assumptions of neoclassical economics and international trade theory. But by incorporating political variables more explicitly into its analysis, OEP provides a bridge between economics and political science - although the span is not yet fully closed. It also accords a central explanatory role to institutions at both the domestic and international levels lacking in its predecessors.

OEP begins with individuals, sectors, or factors of production as the units of analysis and derives their interests over economic policy from each unit's position within the international economy. It conceives of domestic political institutions as mechanisms that aggregate interests (with more or less bias) and structure the bargaining of competing societal groups. Finally, it introduces, when necessary, bargaining between states with different interests. Analysis within OEP proceeds from the most micro- to the most macro-level in a linear and orderly fashion, reflecting an implicit uni-directional conception of politics as flowing up from individuals to interstate bargaining. ${ }^{14}$

Few theorists give equal weight to all steps in this analysis. Most focus on one step-for instance, how institutions aggregate societal interests - and treat others in "reduced form," or as analytic simplifications that are unmodeled in the specific theory at hand. For tractability, scholars focus on one or another step in the process and bracket many obviously varying features of a political-economic environment by treating them as exogenous for purposes of isolating and studying a single causal effect. ${ }^{15}$ One might, for instance, bracket where interests "come from" and study how variable features of domestic institutions aggregate these interests in different ways. In this way, OEP adopts a partial equilibrium or comparative statics approach to theory and knowledge. Employing the classic hypothetico-deductive method, testable hypotheses thus take the form of all else held constant a change in X leads to a change in Y. In reality, of course, all else is not constant, and various research designs are employed to deal with problems of causal inference created by this background variation. ${ }^{16}$ In principle, however, the broadly shared assumptions allow the components to be connected together into a more complete whole, although in practice synthesis remains imperfect.

OEP has made substantial progress. Like any paradigm, it guides research by specifying what is known and unknown, what is fact and anomaly. Originally formulated in the context of trade policy, OEP has been extended to monetary and financial relations (Frieden 1988a, 1991; Bernhard et al. 2003), foreign direct investment (Jensen 2006; Pinto and Pinto 2008), immigration (Leblang et al. 2007), foreign aid (Milner 2006), regulation (Mattli and Woods 2009; Richards 1999), corporate governance (Gourevitch and Shinn 2005), and global governance (Kahler

\footnotetext{
${ }^{14}$ In this way, OEP is a subset of Liberalism, as described by Moravcsik (1997).

${ }^{15}$ Lake and Powell (1999) refer to this as a "boxes-within-boxes" approach.

${ }^{16}$ For scholars working within OEP, a satisfying explanation requires a rigorous and logically specified theory and an appropriately designed test that maximizes variation in the causal variable while controlling for possibly confounding effects. Few studies fully meet this standard, and thus research continues to refine the implications of theory and explore alternative research designs. But in general, scholars sharing this epistemology are willing to sacrifice empirical richness and context for (1) more parsimonious but therefore more fully specified theories, and (2) more narrow but therefore more easily controlled empirical tests. A satisfying explanation in this tradition is one that "knows" well specified causal relationships with some degree of certainty. For a contrast with "British" or constructivist approaches to IPE, see Lake (2009)
} 
and Lake 2003). It now forms a comprehensive approach to explaining a large range of foreign economic policies.

\subsection{Interests}

The fundamental building block of OEP is interest, or how an individual or group is affected by a particular policy. In what may now be regarded as the canonical model of Gene Grossman and Elhanan Helpman (1994, 2002), actors that benefit from a policy are expected to expend resources in the political arena to obtain that policy (as a shorthand, to lobby) up to the point where the marginal cost of that effort equals the marginal benefit (defined either as "more" of the policy or an increased probability of obtaining a fixed policy). Conversely, actors that lose from a policy are expected to lobby against it. In short, politics is fundamentally about winners and losers from alternative policies.

Theories differ in what they assume to be the relevant unit of analysis. Although nearly all theories are fundamentally individualist, for pragmatic purposes theorists bundle individuals into groups that can be reasonably assumed to share (nearly) identical interests. In other words, when a policy affects a set of individuals in the same way, they are typically treated as if they constitute a homogenous group or, for purposes of analysis, a single actor. In some OEP theories, individuals are primary but in most firms, sectors, or factors of production are taken to be the relevant units.

OEP uses economic theory to deduce what types of individuals can be reasonably assumed to share identical interests. A key divide within the approach is between the Ricardo-Viner or specific factors theory of international trade, which assumes that, typically, capital and labor are fixed in particular occupations and, thus, will tend to have similar interests over economic policy, and the Heckscher-Ohlin-Samuelson (HOS) theory of international trade, which assumes that all factors are mobile across occupations within countries and, therefore, capital and labor will possess opposing interests. Stephen Magee (1980) attempted to discern which assumption was more appropriate by studying the lobbying behavior of capital and labor in the trade bill of 1973, and found support for the specific factors approach in his observation that capital and labor almost always testified on the same side of the proposed legislation. This implied that sectors were the appropriate unit of analysis for theories of trade policy. ${ }^{17}$ Alternatively, Michael Hiscox (2002) used cross-industry variations in rates of return as a proxy for factor mobility. In his small sample of industrialized countries, he finds that for the late 19th to the mid-20th centuries, as mass production was introduced, factor mobility for capital and labor generally increased, and from the mid-20th century until today factor mobility has generally decreased, which in turn is broadly confirmed by the changing structure of political interests on trade over the last century. This implies that the relevant units evolved from sectors, to factors, and back to sectors over the course of the last century or more.

Having defined the relevant unit of analysis, OEP goes further to derive interestspreferences over alternative policies - from the distributional implications of alternative economic policies and, in turn, how a group is located relative to others in the

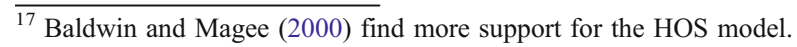


international economy. ${ }^{18}$ Firms vary by whether they are in the tradable or nontradable sectors, produce import-competing or export-competing goods, use imported components, and so on. By knowing a firm's "production profile," as Gourevitch (1986) termed it, OEP predicts how it will be affected, for instance, by policies to increase international openness. Sectors vary by similar characteristics. Factors of production, in turn, vary by their scarcity relative to the world economy (Stolper and Samuelson 1941; Rogowski 1989). Using Mundell's (1957) equivalence conditionthat flows of goods and factors across international borders are equivalent in their effects on relative rates of return-we can derive expectations about how factors will be affected by a large range of economic policies and, thus, identify their interests over those same policies.

Deducing interests from economic theory was a fundamental innovation for OEP, one that makes the approach unique in political economy. Rather than treating them simply by assumption or inferring them from the political actions to be explained, interests are derived from a prior, falsifiable, and empirically robust theory-putting the whole approach on a sound deductive footing. It is on this innovation that the distinctive nature and, indeed, explanatory power of OEP rests. That both the relevant political actors and their interests are defined by their production profile or position in the international economy is the "hard core" of the emergent paradigm. ${ }^{19}$

\subsection{Domestic Institutions}

Institutions aggregate conflicting societal interests, with varying degrees of bias, and condition the bargaining between opposing groups. In weakly institutionalized political systems, like the international system or "failed states," coercive strength is expected to determine political outcomes; on average, and simplifying somewhat, we expect the side with the most guns to win. In highly institutionalized settings, like most domestic political systems, established rules and procedures generally reflect group strength over the long term. But because they often do other valuable things for society, like enhance the credibility of commitments, institutions can develop an independent standing and structure, channel, and sometimes offset brute force in the short term. At any moment, institutions serve to define what political power means in a particular society, whether the competition over policy will be conducted via votes, normally expected to favor labor, via contributions and bribes, often in capital's comparative advantage, or via ideas and argument. In short, institutions determine the "currency" used in the political marketplace and how different political assets are valued.

Political scientists and, increasingly, economists are studying in detail how domestic institutions aggregate interests. OEP is consistent with and draws heavily on the literature on comparative political institutions, much of which is not connected immediately to economic policy (see Cox 1997; Tsebelis 2002). There are many diverse strains in this literature, but among the more relevant findings for IPE are:

- Large constituencies - at the extreme, a single electoral district for the entire country-incline policy towards the general welfare, assumed to be the free

\footnotetext{
$\overline{18}$ On studying preferences more generally, see Frieden (1999).

${ }^{19}$ On hard core and peripheral assumptions in paradigms, see Lakatos (1978).
} 
flow of goods, services, and factors of production, while small constituencies bias policy toward more protectionist groups (Rogowski 1987).

- The more veto points within a political system (actors with the authority to block the enactment of policy), the more likely the status quo is to prevail, reducing the credibility of any promise to adopt political or economic reforms (Cowhey 1993) and, at the same time, reducing the ability of a government to respond effectively to external shocks (MacIntyre 2001).

- Institutionalized legislative participation in foreign policy decision-making provides both the national executive and foreign partners with better information, reducing the problem of reneging on agreements, and additional checks (veto points) on policy change, enhancing credibility and prospects for cooperation (Martin 2000).

- Proportional representation systems produce policy stability and inflexibility, implying less credible commitments to reform and less ability to respond effectively to external shocks, whereas majoritarian electoral systems tend toward policy flexibility and instability, with the opposite effects on credibility and effective response (Rogowski 1999).

Our understanding of how institutions aggregate interests is far more advanced for democracies than for democratizing or autocratic states. Interest aggregation in non-democratic or newly democratic states remains an important area for future research.

Institutions also condition the bargaining between groups, largely by setting the reversion point for policy in the absence of some compromise and defining possible sidepayments, cross-issue deals, and logrolls. For instance, Peter Katzenstein (1985) argues that the small open economies of Europe developed corporatist institutions to facilitate economic adjustment, capital-labor cooperation to moderate wage demands, and compensatory social welfare systems to ease the costs to individuals of economic adversity. Dani Rodrik (1997), Geoffrey Garrett (1998), and others have generalized this argument to all states, finding substantial evidence of an "embedded liberal" compromise (Ruggie 1983) in which social welfare policies are the cost capital pays for economic openness. Similarly, multimember electoral districts, as in Japan, promote particularistic interests and policies, creating socially inefficient rentseeking and economic inflexibility (Ramseyer and Rosenbluth 1993).

OEP recognizes, in a way that the earlier domestic interests approach did not, that interests are central but not enough. However well specified, interests are refracted through political institutions that often have an independent effect on policy choices. What remains distinctive about OEP, however, is its insistence on explicit theorizing of both interests and institutions.

\subsection{International Bargaining}

With domestic interests aggregated through institutions into a national "policy" —or, more accurately, a national ideal point — states then bargain when necessary to influence one another's behavior and to determine the joint outcome of their actions. International institutions, in turn, condition how this bargaining takes place and what outcomes are reached. This is the third and final step in the OEP approach. 
International bargaining is most likely to arise when the policies of one state create externalities for others (Milner 1997b). In many situations, externalities arise from the collective choices of many small economic actors. In these so-called market failures, individually optimal choices lead to collectively suboptimal results. These are well studied dilemmas, even if they remain difficult to resolve. ${ }^{20}$ Even when they are not directly affected by the actions of others, states may also promote international norms and may be willing to pay some price to gain adherents or alter the behavior of possible violators. The effort to promote the "Washington Consensus" on development may be one example of norm driven behavior in the IPE (Stiglitz 2002), and attempts to regulate child sex tourism a possible second (Martin 2003). ${ }^{21}$ Nonetheless, most theories of IPE continue to assume that bargaining occurs mostly as a result of some material externality.

Much research in OEP focuses on how international institutions, like their domestic counterparts, structure bargaining and affect outcomes. There are essentially two approaches that, as Stephen D. Krasner (1991) reminds us, capture different but complementary dimensions of the bargaining game. The first, often referred to as neoliberal institutionalism, sees institutions as sets of rules that facilitate cooperation. By providing information, creating issue linkages, and reducing transactions costs, institutions help states reach Pareto-improving bargains (Keohane 1984; Bagwell and Staiger 2002). Current research in OEP has moved well beyond the sterile debates that dominated political science in the 1990s over whether international institutions "matter," and now focuses on how institutions are designed to achieve the aims of member states. ${ }^{22}$

Particularly important is how states enhance the credibility of their commitments through institutions. Since all agreements must be self-enforcing, international cooperation is possible only when agreements are credible, or in the interests of all parties to carry out under future circumstances. Much of the work on this problem has focused on the issue of sovereign debt, but is easily generalized to other types of transactions. Michael Tomz (2007) looks at the time inconsistency problem in international lending when there is uncertainty about the borrower's willingness to repay, and how states use (and abuse) reputations to solve this problem. Randall Stone (2002) examines the enforcement problem in sovereign lending, which arises when lenders have political incentives not to publish borrowers who default on their commitments. More directly institutional, Xinyuan Dai (2007) argues that even "weak" international institutions empower non-state and domestic actors to provide information and improve state compliance with international rules. J. Lawrence Broz (2002) finds that states that lack domestic transparency and cannot otherwise commit credibly to monetary stability are more likely to fix their exchange rates.

\footnotetext{
${ }^{20}$ Among others, see Frey (1984, Chapter 7) and Sandler (1997).

${ }^{21}$ We can convert normative principles into externalities simply by adding into an individual's utility function a desire, say, not to see children exploited. Yet when there is no direct or indirect impact on a person's welfare other than through the unobservable normative principle, the concept of externality is stretched almost to the breaking point. Nearly any observed behavior can then be "explained" by appeal to externalities.

${ }^{22}$ See Goldstein et al. (2001) and Koremenos et al. (2003). A slightly different approach examines how states construct international organizations as agents to facilitate their aims. See Hawkins et al. (2006).
} 
A second institutionalist approach focuses on bargaining over the gains from cooperation. If the first approach sees institutions as moving states closer to the Pareto frontier, this school emphasizes (the zero sum) movement along the frontier. As in most bargaining models, the key variables in this redistributive game are the relative cost of the reservation point to the parties, their time horizons (discount rates), and their ability to make credible threats and promises. James Fearon (1998) demonstrates that a long "shadow of the future," which in the first approach promotes cooperation via the folk theorem, can also inhibit cooperation by raising the stakes over which the parties are bargaining.

In focusing on distributional conflict, this second line of inquiry implies that cooperation may not necessarily improve social welfare. The logic parallels ideas first developed in the Chicago school of economic regulation (Stigler 1971; Peltzman 1976). Groups may use their national governments to create international institutions that limit competition and produce rents they can appropriate. Robert Bates (1997) describes the International Coffee Organization as a cartel of large coffee producers allied with the large coffee roasters in developed countries that limited supply and raised prices at the expense of coffee consumers. John Richards (1999) finds similar cartel-like behavior in the international aviation regime. In this literature, institutions are understood largely to codify and lock-in outcomes that favor one country or group of countries over another.

Together, interests, institutions, and international bargaining explain the choice of policies by countries and the outcomes experienced by the world economy. As suggested, OEP proceeds towards an explanation in a linear, unidirectional fashion. Although any one analysis may focus more or less on a single step in the causal chain, any complete explanation begins with interests, proceeds to examine the role of domestic institutions, and concludes with bargaining in international institutions and, then, ultimately the policy or outcome to be explained. As I shall argue below, this linear structure of the theory also forms one of its principle limitations.

\subsection{Why Success?}

OEP has arisen as an emergent paradigm in the field of IPE for three reasons. We should not lose sight of these reasons as the approach matures. First, OEP is disciplined by a strong empirical foundation. From its inception, IPE has focused on historical trends in the international economy, both political and economic. Analysts have generally been careful not to mistake a single cross-section for all possible states of the world, but have mined the rich history available to them to test their theories. In turn, considerable attention has been devoted to developing appropriate indicators of trade protection, non-tariff barriers to trade, exchange rate regimes, and so on. Where IPE was originally constrained to case studies or, at best, statistical tests based on very limited data, some of the best new research employs very large time series datasets and powerful econometric tools. Whatever the method, however, IPE remains a strongly empirical science.

Second, OEP emphasizes deductive rigor. Political scientists, especially, have benefited from powerful theories developed in economics. Economists, in turn, have been prompted to take politics and political institutions seriously, and to integrate realistic understandings of political processes into their models. Scholarly debate has 
forced all to clarify the assumptions they make, revealing strengths and limitations, and to state propositions in clear and falsifiable ways, thereby opening arguments to empirical test. By working within agreed standards of scientific inquiry, scholarly interactions and cumulative knowledge are facilitated.

Finally, OEP draws upon and is integrated into broader bodies of theory. Theorists have grounded their analyses in the pure theory of international trade, theories of collective action, and theories of political institutions - all developed in larger disciplines and for other purposes. This not only links OEP to broader research programs and facilitates cross-fertilization, but prevents analysts from reinventing the wheel each time they sit down at their computers. Norms of theoretical rigor disciplined by empirical facts are now deeply inculcated in scholars of OEP, providing many reasons for optimism about the long term success of this emergent paradigm.

\section{Critique}

As noted, all paradigms by definition privilege one set of assumptions, methods, and epistemologies and, by implication, one conception of political economy over others. Scholars cannot reach agreement that one set of assumptions is likely to prove productive in building and testing theories, for instance, without necessarily excluding other possible sets of assumptions. Any approach that is sufficiently capacious to encompass many possible assumptions is likely to be vacuous or, at least, indeterminate. For this reason, the stakes of academic debate are often quite high.

Reflecting its status as an emergent paradigm, OEP has been the target of significant criticism. Critics charge that its conception of interests is too materialist and too narrow (Keohane 2009; Katzenstein 2009; Farrell and Finnemore 2009), that it ignores the constitutive (as opposed to regulative) power of institutions (Katzenstein 2009, 126), and that it disregards structural (as opposed to bargaining) power in the international economy (Keohane 2009, 39). In its focus on micro-level and individual incentives, it fails to pay sufficient attention or, worse, is blinded to big, macro-level changes in the international economy and lacks a synthetic interpretation of change (Keohane 2009). Leveled by some of the founders of modern IPE, these are valid criticisms that proponents of OEP need to take seriously.

The first two criticisms - on interests and the constitutive nature of institutionsare inherent in the paradigm. As above, the hard core assumption of OEP is that interests are determined largely by a unit's production profile or position in the international division of labor. In this way, interests are understood to be thinly social-in that they are a product of a larger set of social interactions, the international economy - and largely materialist. ${ }^{23}$ Deducing interests from the unit's

\footnotetext{
${ }^{23}$ By thinly social, I mean that interests are not entirely internal to the unit but are not constituted by any larger, normative or ideational environment. New work seeks to open up the question of interests by examining how gender, religion, and other attributes interact with a unit's production profile. Research shows that religion (Scheve and Stasavage 2006) and gender differences (Burgoon and Hiscox 2003; Goldstein et al. 2007) are important to how individuals experience or interpret their economic policy interests. Cross-national surveys of attitudes toward trade, now in progress, promise important insights. This research enriches but is not inconsistent with the notion of interest otherwise derived from the clear and distinct predictions of the specific factors and HOS theories.
} 
position in the international division of labor via established economic theory is the great innovation and strength of OEP, and perhaps in the eyes of its critics its greatest weakness. As part of the hard core of the paradigm, however, this assumption cannot be altered significantly without altering or, indeed, vitiating the paradigm itself.

Proponents of OEP, I think, are mindful of the inherent limits of this assumption. There are many dimensions of interests that cannot be derived from the production profile of an individual or group. Embodying the second and third dimensions of power (Lukes 1977; Barnett and Duvall 2005), institutions do shape how individuals or groups conceive of their interests. As descriptions of the real world, these statements are undoubtedly correct. The question is not whether OEP or any other theory accurately captures all aspects of the real world, but what empirical regularities are missed or perhaps incorrectly estimated by the particular theoretical simplifications employed and, importantly, whether some other approach that does capture these aspects of reality contains excess empirical content or explains sufficiently more than OEP to justify the additional theoretical complexity. ${ }^{24}$ To note that a theory simplifies and excludes some aspects of reality is a truism. When critics charge that OEP does not include this or that, the only possible response can be "Yes, as does any theory or paradigm." To identify the substantive consequences of these simplifications and to offer an alterative, more empirically powerful theory is a considerably harder challenge.

Other criticisms, on structural power and theories of change, can be accommodated, at least in part, within OEP. The criticisms are justified given the current state of theory, but they do not challenge the hard core of the paradigm. Rather, they offer interesting new avenues for extending the approach. The root of these criticisms, in my view, is in the linear conception of politics embedded in OEP which diverts attention from the feedback effects of decisions taken at the international level on the constellation of interests and institutions within societies. In an often-cited, still relevant, but seldom heeded critique, Gourevitch (1978) referred to such effects as the "second image reversed." By identifying and relaxing several peripheral assumptions now made by theorists, OEP can move toward a more dynamic and politically richer theory. Specifically, by relaxing the small country and constant returns to scale assumptions of traditional economic theory, and building on the recursive nature of international institutions, OEP can go some distance toward incorporating into existing theory structural power, historical contingency, and political dynamics and, thereby, contribute to our understanding of macro-level change in the international political economy.

\subsection{International Market Power}

The issues of structural power and, often, big, macro-level change revolve around the rise and decline of major industrial and trading states. The supposed decline of the United States in the 1970s and 1980s, the rise of Japan in the same period, or the

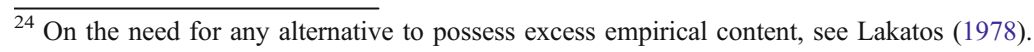


rise of China in the 21 st century all unsettle international economic relations and should, by implication, be subjects of study in IPE. OEP has, to date, been largely silent on these changes, but this need not be the case.

OEP typically begins with the "small country" assumption of international economic theory that production and consumption in any single state are sufficiently small relative to global totals that all actions, including government policy, have no noticeable effect on world prices. ${ }^{25}$ Relaxing this assumption, however, has long been recognized to open the possibility of welfare-improving government interventions through import barriers or export restrictions, known collectively as optimal tariffs. By restricting imports or exports, governments can shift the terms of trade to their advantage sufficiently to improve their national welfare even at the expense of global welfare. A contemporary example is Saudi Arabia which by restricting its production of crude oil raises world prices more than enough to offset the revenue forgone by not selling all it could produce. Although optimal tariffs have not been a focus of OEP, in drawing on the same economic theories of interest discussed above, they are not inconsistent with the basic framework and can be easily incorporated at the international bargaining stage (Gowa 1994). Indeed, Kyle Bagwell and Robert Staiger (2002) argue that it is precisely the ambition to cooperate in restraining these nationally optimal but collectively suboptimal tariffs that motivates the GATT/WTO.

Relaxing the small country assumption and recognizing that countries can act in ways that affect international prices, however, has two sets of effects that, although they can be incorporated into OEP, have not yet been theorized or considered at length. Both suggest that rather than being exogenous to politics, interests are in fact endogenous and the product of political strategies and manipulations.

First, in addition to reducing global welfare, optimal tariffs and other restrictions in one country can have important distributional implications in other countries. Optimal tariffs work by altering international prices. As we know from both the specific factors and HOS models, shifts in relative prices will affect groups/factors within countries differently, depending on the structure of comparative advantage. Groups or factors affected by a decline in the relative price of their goods will suffer disproportionately. If the effect on international prices is indeed large enough to shift rents to the home country, this distributional effect may well be substantial.

In the case of oil prices during the first half of 2008, for instance, oil exporting countries, led by Saudi Arabia, took advantage of tightening market conditions, largely brought on by the rapid economic growth of China and India, to reduce production and push real prices back to their historic highs first reached in the late 1970s. This increase harmed the terms of trade for all oil importing countries, but it inflicted disproportionate harm on countries and industries that use oil relatively intensively. With traditionally low prices for oil and, thus, a history of profligate energy usage, higher oil prices affected the American economy more severely than other advanced industrialized countries. In turn, industries that use energy intensively, like heavy manufacturing, were harmed more than other sectors. And industries that produced goods that use energy intensively-like automobiles, and

\footnotetext{
${ }^{25}$ Although typically stated at the country level, the assumption is more accurately framed at the industry or product level. For most goods most of the time, this assumption may not be unreasonable.
} 
especially large, fuel inefficient trucks - were devastated, leading to what may be the final collapse of the American automobile industry. Perhaps even more important politically, regions within the United States that use energy intensively- the upper Midwest where winters are cold, the South where summers are hot, and rural areas in both where commutes tend to be substantially longer in distance-suffered more than the coastal areas. ${ }^{26}$ While gasoline prices are higher along the coasts, in those areas total oil costs average less than five percent of personal income; in rural counties in the upper Midwest and parts of the South, however, oil can consume up to $16 \%$ of personal income. That the latter are also "Red" leaning states helps account for the politicization of oil prices and policies in the 2008 presidential campaign and the resonance for many rank-and-file Republicans of the chant "drill, baby, drill." In this case, at least, politically determined international price movements, though optimal from the viewpoint of oil exporters, had politically important distributional effects not only between but within other countries as well. The distributional effects of optimal tariffs on other countries should properly be a core subject of OEP.

Second, countries may also affect global prices through economically sub-optimal but politically motivated policies. The distributional effects created by altering world prices is not limited to "optimal" import or export restrictions. Although the intent is not to improve national welfare by earning rents at the expense of foreign producers or consumers, large politically motivated price distortions can have important effects not only at home but also abroad.

Agricultural policy in the advanced industrialized states, for instance, clearly distorts international prices in unfortunate ways not only for consumers in those countries who pay more for food but for producers in other countries who lose markets for their agricultural goods. In the name of food security, preserving the family farm, or just plain old special interest politics, virtually every advanced industrialized democracy subsidizes agriculture. The overproduction of food in industrialized states leads to fewer imports, and therefore lower demand and prices for agricultural commodities sold by foreign producers; the dumping of excess production by industrialized countries, often in the name of "food aid," further depresses global prices for foodstuffs. The overproduction of food in industrialized countries necessarily reduces profits and incentives for production for farmers in countries that might otherwise specialize in agriculture. It also distorts patterns of comparative advantage. Given world prices, typically small countries that would otherwise produce food still specialize in "something," just not the industry that "nature" would have selected or that best uses their factor endowments. Rather than farming, labor and land are put to their next best use, with the former often finding employment in the bloated services sector. ${ }^{27}$

\footnotetext{
${ }^{26}$ Clifford Krauss, "Rural U.S. Takes Worst Hit as Gas Tops \$4 Average,” New York Times, June 9, 2008. Available at: http://www.nytimes.com/2008/06/09/business/09gas.html?scp=14\&sq=oil+price+share+ income\&st=nyt. The interactive map is especially interesting.

${ }^{27}$ Developing countries bear some responsibility for the distortions in production here as well. Although resources are driven out of agriculture by artificially low international prices, that they often fail to find a second best use in another export industry and end up in the service sector or informal economy is likely the result of distorted policies within the developing country itself.
} 
The overproduction of food in industrialized countries also has political implications in developing countries. As resources are driven out of agriculture by artificially low international prices, the farm sector becomes less politically important than it would otherwise be, leading to further distortions in public policy. The effects of these agricultural price distortions are evident in the failure of the Doha Round of the WTO. Clearly, states that would benefit from agricultural trade liberalization are engaging in hard bargaining with the aim of opening up industrialized country markets, and are willing to run some risk of bargaining failure to maximize their leverage. But equally important, the agricultural producers who would otherwise be forces for liberalization within their own developing economies are artificially diminished (or do not exist at all) and cannot play the role of counterweight to the comparatively disadvantaged sectors (usually manufacturing) that demand continued protection. As the result of biased international prices, developing country farmers cannot bring enough pressure to bear on industrialized countries directly to change their policies, but they also cannot produce liberalization in other products at home to induce the developed countries to make further concessions either. By insisting on protecting their own farmers, the advanced industrialized countries are disarming and undermining politically the most important forces for liberalization in developing markets.

The profound effects of policy-induced price distortions on "foreign" interests is best observed, I think, in Britain's much analyzed repeal of the Corn Laws in 1846an actual case where these distortions were eventually removed. At that time, trade policy in the United States was essentially split along sectional lines (see James and Lake 1989). The Northeast, dominated by nascent manufacturers, was strongly protectionist. The South, dependent on British markets for cotton and tobacco, was steadfastly free trade. The Midwest, rapidly growing and searching for markets for its wheat, corn, and other agricultural products, was the swing voting bloc. With the British market closed against its goods, the Midwest threw its weight behind the Northeast protectionists, hoping to stimulate increased domestic specialization according to internal comparative advantage. This was not the region's preferred policy, but a clear second or third best choice. Once Britain repealed its Corn Laws, however, the Midwest swung immediately into a free trade coalition with the South and ushered in a 15 year period of trade liberalization broken only by the Civil War. Indeed, it was not by coincidence that, although the bill had been marked up in committee months earlier, debate in the House of Representatives on the liberal Walker Tariff began the very day Congress received official notification of Britain's historic repeal. The prospect of new markets in the world's then largest industrial power transformed the politics of American trade policy.

By taking international prices as exogenous, OEP is blinded to these indirect or feedback effects on politics and policies in other countries. Tariffs need not be optimal to have profound effects not only on those who choose to use them but on the targets of these policies as well. Scholars of OEP need to be far more attentive to the general effects of policy-induced price distortions, and doing so first requires shedding the simplistic assumption that no country can affect international demand and supply. This form of structural power, as critics term it, matters. As noted above, both dependency theory and hegemonic stability theory, and the concerns that gave rise to these approaches, resonate with contemporary attempts to theorize more 
rigorously about how national actions affect relative prices and how these prices, in turn, alter domestic interests and policy. Although these prior analytic frameworks failed to mature into sound theory, this earlier work may yet prove to be fertile soil for new models of how international power matters in IPE.

\subsection{Increasing Returns to Scale}

In ways similar to the rise and fall of countries above, concerns with structural power and economic dynamics relate to changes in the structure of comparative advantage, and especially the rise of new industries with large economies of scale and, therefore, geographic agglomeration. OEP is premised almost entirely on the assumption, common to both specific factors and HOS trade theory, that all production is characterized by constant returns to scale (a doubling of inputs, for instance, leads to a doubling of output). This implies, in turn, that countries will engage in inter-industry trade, sometimes referred to as "North-South" trade to emphasize differences in factor endowments. Yet, depending on how one classifies goods, one-quarter or more of international exchange is comprised of intra-industry trade, or trade within the same product categories. ${ }^{28}$ Economists have developed sophisticated models of increasing returns to production (a doubling of inputs leads to more than a doubling of output) or economies of scale (EoS) to explain the modern burst of intra-industry trade. Such models show that even with identical factor endowments, technology, and consumer tastes, trade between countries will still occur. Internal EoS (specific to the firm) lead to imperfect competition (monopoly or monopolistic competition) and international trade in similar products, while external EoS (specific to the industry) may or may not produce complete specialization (depending on initial country size). Although not a subject of significant research, allowing for variations in the returns to scale is entirely consistent with OEP and can be incorporated into existing theory, but often with surprising implications.

For the political economy of trade, the most important implication of EoS production is that the pattern of specialization and, thus, any distributional effects are indeterminate. In a world of increasing returns to scale in which countries possess identical factor endowments, for instance, specialization will still occur but is entirely dependent on random perturbations. Similarly, small differences in country size may lead to decisive differences in who specializes in what. In an important unpublished paper, the most serious attempt to examine the distributional implications of EoS trade of which I am aware, Rogowski (1996) deduces that political cleavages and conflict are likely to arise between increasing and constant returns to scale industries, between traded and non-traded goods producers, and (if assets are specific to an industry or even "sticky") between active workers and retirees/consumers, regions, and possibly ethnic groups within countries. The political battles, moreover, will be fought over social welfare policy, industrial policy, immigration and foreign investment policies, political institutions, imperialism (size of country) and supranationalism (regionalism, customs unions, etc.). Yet,

\footnotetext{
${ }^{28}$ Skeptics argue that what appears to be intra-industry trade is simply an artifact of an antiquated and inappropriate system of classification of traded goods.
} 
how these cleavages arise and battles unfold in any single country depend on random initial conditions or shocks anywhere in the world that advantage producers in one country relative to others. Similarly, Kerry Chase (2005) and Helen Milner (1997a) argue that EoS industries are a driving force behind regional trade liberalization, but this too is highly contingent on the optimal size of firms and the arbitrary sizes of the countries within the region (as a proxy for consumer demand).

Given the sensitivity of outcomes to initial conditions, government policy may also have a significant effect - the "created" comparative advantage behind industrial policy (Johnson 1982; Zysman and Tyson 1983). Governments may seek to protect a firm/industry now disadvantaged by an arbitrary but decisive "shock." Or they may try to seize competitive advantages over other possible producers, a branch of inquiry that developed into "strategic trade theory" (Brander and Spencer 1985; Krugman 1986). In a variant of the traditional infant industry argument, strategic trade theory demonstrated that governments could in principle subsidize production sufficiently in its initial stages to gain a permanent cost and locational advantage for industries with increasing returns to scale. In either case, once we admit that government policy can affect the pattern of specialization, we must recognize that interests - the foundation of any OEP analysis - are themselves politically-induced phenomena.

For EoS trade, at least, interests can no longer be taken as exogenous to politics but may actually be the product of international politics. The pattern of comparative advantage and production in open economies is not set by factor endowments that are relatively slow to change, but by initial conditions combined with both chance and government policy. Explicating fully the distributional implications of EoS trade will be essential to further theoretical and empirical progress in OEP. If the distributional implications are as sensitive to initial conditions and actions by governments as current theory suggests, future OEP analyses will have to focus much more fully on the contingent, path dependent factors long emphasized by more historically oriented scholars. Importantly, however, a new focus on EoS industries will help OEP capture more elements of structural power and industrial dynamics in the international economy seen as both missing and central by its critics.

\subsection{The Power of International Institutions}

As we have seen, OEP expects international institutions to play a key role in facilitating cooperation and, more importantly for this critique, structuring the bargaining between states. They are part of the third link in a one-way causal chain that starts with interests, moves through domestic institutions, and ends with international bargaining. This is seen most clearly, perhaps, in the so-called Schelling conjecture, which suggests that domestic constraints improve a leader's bargaining strength abroad. As Robert Putnam (1988) and Helen Milner (1997b) have shown, domestic interests and institutions do affect international bargaining and cooperation. But these examples also make plain that the levels of OEP are typically assumed to cumulate in one direction - from interests to institutions to international bargaining. Yet, if international institutions really matter, they will alter the interests and possibly institutions within states as well. This feedback from the international political economy to the domestic arena is now almost entirely ignored in OEP, but 
need not be. ${ }^{29}$ Indeed, in a way fully consistent with the core assumptions of the paradigm, international institutions may actually create an important endogenous dynamic with important effects on politics.

In structuring the bargaining between states, institutions favor one state over another, of course, but may also favor selected interests in those states over other interests. Even when simply facilitating cooperation international institutions can benefit particular groups within states while harming others. By creating "winners" and "losers" from particular outcomes, international institutions privilege and reward some countries and groups and harm others. In ways similar to optimal tariffs, the effects of international phenomena on domestic groups can be quite significant.

While unfavorable international policies might be expected to compel domestic losers to fight harder, the losers are in reality weakened further by these outcomes. Presumably, when faced with the prospect of political defeat, the losers have already done all they desired or could to forestall this result. Ex post, they would likely make the same choices, on average. But once burdened with unfavorable policies, the income of the group will fall and its resources will contract; this reduces further incentives for new investments in the enterprise and increases incentives to invest in or migrate to new industries, exacerbating the initial result. Depending on the degree of asset specificity, depreciation rates, and transactions costs, this process of asset reallocation from disfavored to favored policy areas will be faster or slower, but in the face of unfavorable policies the resources and political clout of the losers will inevitably decline relative to the resources and political power of the winners (Rogowski 1989).

This rebalancing of political forces is clearly evident in the "creative destruction," as Joseph Schumpeter described technological change in another context, of the current international free trade regime embodied in the WTO. As an organization founded and designed to promote free trade, the rules of the WTO clearly benefit some groups over others, as highlighted in the continuing controversy over the institution. By opening markets, limiting the types of protection that can be used to bolster declining industries, explicitly creating reciprocity in market access, and excluding most environmental and social considerations from the agenda, the WTO favors the abundant factors of production and the comparatively advantaged sectors in each country. Over time, in turn, free trade has systematically harmed scarce factors of production and shrunk their political strength, as witnessed by the declining labor movements of most industrialized countries; correspondingly, comparatively disadvantaged industries have slowly disappeared, as in the footwear industry in North America, once a vibrant force in the protectionist coalition. In this way, the WTO and the free trade regime it supports have fundamentally reshaped the economic and political structures of its members in ways that expand and strengthen groups supportive of free trade and shrink and weaken the forces of protectionism (Hathaway 1998). Since the structure of comparative advantage continues to evolve, new groups are always thrust into the protectionist fringe, but the political equipoise within many countries has been decisively turned over time in ways that reinforce the initial bias in policy towards free trade. As a result of this evolution, the

${ }^{29}$ For an exception, see Davis (2003). 
constellation of interests in North America, Europe, and Japan over trade policy is vastly different today from that in the 1960s and 1970s.

This dynamic reshaping of interests is an inevitable if under-appreciated byproduct of the fact that international institutions do matter in world politics. To the extent that institutions bias policy in particular directions, and that bias has distributional implications for different groups, the structure of interests within societies must change as well. The example of trade is likely to be replicated in all areas of IPE, and possibly beyond in other institutionalized arenas. If so, the composition of interests within a society at any given time is not independent of the international institutions created and promoted at some previous moment. The longer the period under examination, moreover, the more likely the interests at play will themselves be the product of prior institutional choices. OEP now treats societal interests as exogenous and, thus, constitute the "ultimate" independent variable. The more international institutions matter for politics, the less helpful the "linear" treatment of politics will be. Nonetheless, by linking institutional effects to changes in international prices, as with trade openness, we can still predict with some degree of clarity who will win from particular policies and who will lose, and how this will affect the political strength of the groups over time. That there is feedback from institutions on interests makes the analytic task harder, but connecting this to international price effects is likely to still yield important insights.

\subsection{Implications}

All three of these critiques challenge the notion that interests, the fundamental building block of OEP, are fixed and exogenous, or can be safely treated as such. Each suggests that interests are themselves political constructs, the product of some past or present set of political choices. The importance of these feedback effects suggests the need within OEP for a less linear view of politics and a more general rather than partial equilibrium view of theory and testing.

More important, however, by relaxing peripheral assumptions on country size and returns to scale, and attending to the distributional implications of international institutions and policy outcomes more generally, OEP has the tools to address concerns with structural power and economic dynamics that lie at the center of many of the criticisms leveled at the emergent paradigm. It remains to be seen whether these tools can address adequately issues of power and change, or whether some other approach might prove superior. The critics raise important concerns that can, hopefully, stimulate new and important directions for research in OEP and, more generally, IPE.

\section{Conclusion}

In three short decades, but a moment in academic time, IPE has grown into a true interdiscipline, combining some of the best of political science and economics, centered on a emergent paradigm that structures knowledge, generates puzzles, and identifies areas likely to yield profitable future research. Despite its successes, OEP is not perfect. As indicated, many refinements and extensions are possible and, 
indeed, required in the years ahead. Nonetheless, OEP is a powerful approach that still promises future rewards. By working within broadly shared assumptions, methods, and epistemologies, scholars have built better and more refined theories, tested and accepted or rejected specific hypotheses, created new and more theoretically appropriate measures of key theoretical constructs, and produced better causal explanations of a variety of international economic policies. We understand the causes of trade, capital market, migration, and foreign investment policies better today than even a decade or two ago.

In my view, OEP is a model approach for the study of international institutions more generally. As noted, interests filtered through the structure of international prices and deduced from economic theory are key to OEP's success as an explanatory framework. Other approaches lack clear theories of interests, as do many issue areas other than the economy. As a result, in many studies of international institutions, interests are often treated in an arbitrary or inductive manner and produce, at best, propositions that are hard to falsify. This is true not only of earlier, more functional theories of international regimes (Keohane 1984), but also of more recent models of institutional design (Goldstein et al. 2001; Koremenos et al. 2003). Rather than building ever more sophisticated models of institutions per se, scholars of security, the environment, human rights and other important substantive topics might be better served by developing theories of and focusing attention on the interests of actors.

By placing international institutions into a broader theory of politics, OEP is also better able to specify how, when, and why such institutions affect the play of politics within and between countries than more narrowly drawn theories. OEP has generated important insights into how international institutions enhance the credibility of international agreements, influence bargaining between states, and even alter the interests of individuals, groups, and states. Many of the insights about international institutions from OEP have been generalized to other issue areas, especially on the important role of international institutions in enhancing the credibility of agreements. Nonetheless, debate continues on the extent to which international institutions "matter," especially in security affairs (Mearsheimer 1994; but see Haftendorn et al. 1999). Ultimately, this debate can only be resolved by general theories that identify the actors and their interests, address the role of domestic institutions in aggregating those social forces, specify the bargaining process between states and how international institutions modify outcomes from what we would expect from a pure "power politics" perspective, and, of course, endogenize the feedback effects from institutions and other international factors on the fundamental building block of interests.

Open Access This article is distributed under the terms of the Creative Commons Attribution Noncommercial License which permits any noncommercial use, distribution, and reproduction in any medium, provided the original author(s) and source are credited.

\section{References}

Bagwell, K., \& Staiger, R. W. (2002). The economics of the world trading system. Cambridge, MA: MIT. Baldwin, R. E. (1985). The political economy of U.S. import policy. Cambridge, MA: MIT. 
Baldwin, R. E., \& Magee, S. P. (2000). Is trade policy for sale? Congressional voting on recent trade bills. Public Choice, 105, 79-101.

Barnett, M., \& Duvall, R. (Eds). (2005). Power in global governance. New York: Cambridge University Press.

Bates, R. H. (1997). Open-economy politics: The political economy of the world coffee trade. Princeton, NJ: Princeton University Press.

Bernhard, W., Lawrence Broz, J., \& Clark, W. R. (Eds). (2003). The political economy of monetary institutions. Cambridge, MA: MIT.

Brander, J. A., \& Spencer, B. J. (1985). Export subsidies and international market share rivalry. Journal of International Economics, 18, 83-100.

Broz, J. L. (2002). Political system transparency and monetary commitment regimes. International Organization, 56, 861-887.

Burgoon, B. A., \& Hiscox, M. J. (2003). The mysterious case of female protectionism: Gender bias in attitudes toward international trade. Presented at the Annual Meeting of the American Political Science Association, Philadelphia, PA.

Caporaso, J. A., \& Levine, D. P. (1992). Theories of political economy. New York: Cambridge University Press.

Cardoso, F. H., \& Faletto, E. (1979). Dependency and development in Latin America. Berkeley, CA: University of California Press.

Cassing, J. H., McKeown, T. J., \& Ochs, J. (1986). The political economy of the tariff cycle. American Political Science Review, 80, 843-862.

Caves, R. E. (1976). Economic models of political choice: Canada's tariff structure. Canadian Journal of Economics, 9, 278-300.

Chase, K. A. (2005). Trading blocs: States, firms, and regions in the world economy. Ann Arbor, MI: University of Michigan Press.

Cohen, B. J. (2007). The transatlantic divide: why are American and British IPE so different? Review of International Political Economy, 14, 197-219.

Cohen, B. J. (2008). International political economy: An intellectual history. Princeton, NJ: Princeton University Press.

Cohen, B. J. (2009). Striking a nerve. Review of International Political Economy, 16, 136-143.

Cooper, R. N. (1968). The economics of interdependence: Economic policy in the Atlantic community. New York: McGraw-Hill.

Cowhey, P. F. (1993). Domestic institutions and the credibility of international commitments: Japan and the United States. International Organization, 47, 299-326.

Cox, G. W. (1997). Making votes count: Strategic coordination in the world's electoral systems. New York: Cambridge University Press.

Dai, X. (2007). International institutions and national policies. New York: Cambridge University Press.

Davis, C. L. (2003). Food fights over free trade: How international institutions promote agricultural trade liberalization. Princeton, NJ: Princeton University Press.

Farrell, H., \& Finnemore, M. (2009). Ontology, methodology, and causation in the American school of international political economy. Review of International Political Economy, 16, 58-71.

Fearon, J. D. (1998). Bargaining, enforcement, and international cooperation. International Organization, $52,269-305$.

Frank, A. G. (1966). The development of underdevelopment. Monthly Review, 28, 17-31.

Frey, B. S. (1984). International political economics. New York: Basil Blackwell.

Frieden, J. A. (1988a). Capital politics: creditors and the international political economy. Journal of Public Policy, 8, 265-286.

Frieden, J. A. (1988b). Sectoral conflict and U.S. foreign economic policy, 1914-1940. International Organization, 42, 59-90.

Frieden, J. A. (1991). Invested interests: the politics of national economic policies in a world of global finance. International Organization, 45, 425-451.

Frieden, J. A., Lake, D. A., \& Schultz, K. A. (2009). World politics: Interests, interactions, and institutions. New York: W. W. Norton.

Frieden, J. (1999). Actors and Preferences in International Relations. In D. A. Lake \& R. Powell (Eds.), Strategic Choice and International Relations. Princeton: Princeton University Press.

Friedman, T. L. (2000). The Lexus and the Olive tree: Understanding globalization. Updated and expanded. New York: Anchor Books.

Furtado, C. (1973). The concept of external dependence in the study of underdevelopment. In C. K. Wilber (Ed.), The political economy of development and underdevelopment. New York: Random House. 
Garrett, G. (1998). Partisan politics in the global economy. New York: Cambridge University Press.

Gilpin, R. (1972). The politics of transnational economic relations. In R. O. Keohane \& J. S. J. Nye (Eds.), Transnational relations and world politics. Cambridge, MA: Harvard University Press.

Gilpin, R. (1975). U.S. power and the multinational corporation: The political economy of foreign direct investment. New York: Basic Books.

Gilpin, R. (1977). Economic interdependence and national security in historical perspective. In K. Knorr \& F. N. Trager (Eds.), Economic issues and national security. Lawrence, KS: Regents Press of Kansas.

Goldstein, J. (1988). Ideas, institutions, and American trade policy. International Organization, 42, 179217.

Goldstein, J., Kahler, M., Keohane, R. O., \& Slaughter, A.-M. (Eds). (2001). Legalization and world politics. Cambridge, MA: MIT.

Goldstein, J., Margalit, Y., \& Rivers, D. (2007). Producer, consumer, family member: The relationship between trade attitudes and family status. Manuscript. Stanford, CA: Stanford University.

Gourevitch, P. (1977). International trade, domestic coalitions, and liberty: comparative responses to the crisis of 1873-1896. Journal of Interdisciplinary History, 8, 281-313.

Gourevitch, P. (1978). The second image reversed: the international sources of domestic politics. International Organization, 32, 881-912.

Gourevitch, P. (1986). Politics in hard times: Comparative responses to international economic crises. Ithaca, NY: Cornell University Press.

Gourevitch, P., \& Shinn, J. (2005). Political power and corporate control: The new global politics of corporate governance. Princeton, NJ: Princeton University Press.

Gowa, J. (1983). Closing the gold window: Domestic politics and the end of Bretton Woods. Ithaca, NY: Cornell University Press.

Gowa, J. (1994). Allies, adversaries, and international trade. Princeton, NJ: Princeton University Press.

Grossman, G. M., \& Helpman, E. (1994). Protection for sale. American Economic Review, 84, 833-850.

Grossman, G. M. \& Helpman, E. (2002). Interest groups and trade policy. Princeton, NJ: Princeton University Press.

Haftendorn, H., Keohane, R. O., \& Wallander, C. A. (Eds). (1999). Imperfect unions: Security institutions over time and space. New York: Oxford University Press.

Hathaway, O. (1998). Positive feedback: the impact of trade liberalization on industry demands for protection. International Organization, 52, 575-612.

Hawkins, D. G., Lake, D. A., Nielson, D. L., \& Tierney, M. J. (Eds). (2006). Delegation and agency in international organizations. New York: Cambridge University Press.

Hiscox, M. J. (2002). International trade and political conflict: Commerce, coalitions, and mobility. Princeton, NJ: Princeton University Press.

Ikenberry, G. J., Lake, D. A., \& Mastanduno, M. (Eds). (1988). The state and American foreign economic policy. Ithaca, NY: Cornell University Press.

James, S., \& Lake, D. A. (1989). The second face of hegemony: Britain's repeal of the Corn Laws and the American Walker tariff of 1846. International Organization, 43, 1-29.

Jensen, N. M. (2006). Nation-states and the multinational corporation: A political economy of foreign direct investment. Princeton, NJ: Princeton University Press.

Johnson, C. (1982). MITI and the Japanese miracle: The growth of industrial policy, 1925-1975. Stanford, CA: Stanford University Press.

Kahler, M., \& Lake, D. A. (Eds). (2003). Governance in a global economy: Political authority in transition. Princeton, NJ: Princeton University Press.

Katzenstein, P. J. (Ed). (1978). Between power and plenty: Foreign economic policies of advanced industrial states. Madison, WI: University of Wisconsin Press.

Katzenstein, P. J. (1985). Small states in world markets: Industrial policy in Europe. Ithaca, NY: Cornell University Press.

Katzenstein, P. J. (2009). Mid-Atlantic: sitting on the knife's sharp edge. Review of International Political Economy, 16, 122-135.

Keohane, R. O. (1984). After hegemony: Cooperation and discord in the world political economy. Princeton, NJ: Princeton University Press.

Keohane, R. O. (2009). The old IPE and the new. Review of International Political Economy, 16, $34-46$.

Keohane, R. O., \& Nye, J. S., Jr. (Eds). (1972). Transnational relations and world politics. Cambridge, MA: Harvard University Press.

Keohane, R. O., \& Nye, J. S., Jr. (1977). Power and interdependence: World politics in transition. Boston, MA: Little, Brown. 
Kindleberger, C. P. (1951). Group behavior and international trade. Journal of Political Economy, 59, $30-46$. Kindleberger, C. P. (1969). American business abroad. New Haven, CT: Yale University Press.

Kindleberger, C. P. (1973). The world in depression, 1929-1939. Berkeley, CA: University of California Press.

Koremenos, B., Lipson, C., \& Snidal, D. (Eds). (2003). The rational design of international institutions. New York: Cambridge University Press.

Krasner, S. D. (1976). State power and the structure of international trade. World Politics, 28, 317-347.

Krasner, S. D. (1978). Defending the national interest: Raw materials investments and U.S. foreign policy. Princeton, NJ: Princeton University Press.

Krasner, S. D. (Ed). (1983). International regimes. Ithaca, NY: Cornell University Press.

Krasner, S. D. (1985). Structural conflict: The third world against global liberalism. Berkeley, CA: University of California Press.

Krasner, S. D. (1991). Global communications and national power: life on the Pareto frontier. World Politics, 43, 336-366.

Krugman, P. R. (Ed). (1986). Strategic trade policy and the new international economics. Cambridge, MA: MIT.

Kuhn, T. S. (1970). The structure of scientific revolutions. Second (Enlarged ed.). Chicago: University of Chicago Press.

Lakatos, I. (1978). The methodology of scientific research programmes: Philosophical papers, Vol. 1. Edited by J. Worrall, \& G. Currie. New York: Cambridge University Press.

Lake, D. A. (1993). Leadership, hegemony, and the international economy: naked emperor or tattered monarch with potential? International Studies Quarterly, 37, 459-489.

Lake, D. A. (2009). Trips across the Atlantic: theory and epistemology in IPE. Review of International Political Economy, 16, 47-57.

Lake, D. A., \& Powell, R. (Eds). (1999). Strategic choice and international relations. Princeton, NJ: Princeton University Press.

Lavergne, R. P. (1983). The political economy of U.S. tariffs: An empirical analysis. Toronto: Academic.

Leblang, D., Fitzgerard, J., \& Teets, J. (2007). Defying the law of gravity: The political economy of international migration. Manuscript. Boulder, CO: University of Colorado.

Lukes, S. (1977). Power: A radical view. London: Macmillan.

MacIntyre, A. (2001). Institutions and investors: the politics of economic crisis in Southeast Asia. International Organization, 55, 81-122.

Magee, S. P. (1980). Three simple tests of the Stolper-Samuelson theorem. In P. Oppenheimer (Ed.), Issues in international economics. London: Oriel.

Magee, S. P., Brock, W. A., \& Young, L. (1989). Black hole tariffs and endogenous policy theory: Political economy in general equilibrium. New York: Cambridge University Press.

Marini, R. M. (1972). Brazilian subimperialism. Monthly Review, 23, 14-24.

Martin, L. L. (2000). Democratic commitments: Legislatures and international cooperation. Princeton, NJ: Princeton University Press.

Martin, L. L. (2003). The leverage of economic theories: Explaining governance in an internationalized industry. In M. Kahler \& D. A. Lake (Eds.), Governance in a global economy: Political authority in transition. Princeton, NJ: Princeton University Press.

Mattli, W., \& Woods, N. (Eds). (2009). The politics of global regulation. Princeton, NJ: Princeton University Press.

McKeown, T. J. (1984). Firms and Tariff regime change: explaining the demand for protection. World Politics, 36, 215-233.

McNamara, K. R. (2009). Of Intellectual monocultures and the study of IPE. Review of International Political Economy, 16, 72-84.

Mearsheimer, J. J. (1994). The false promise of international institutions. International Security, 19, 549.

Milner, H. V. (1988). Resisting protectionism: Global industries and the politics of international trade. Princeton, NJ: Princeton University Press.

Milner, H. V. (1997a). Industries, governments, and regional trade blocs. In E. Mansfield \& H. V. Milner (Eds.), The political economy of regionalism. New York: Columbia University Press.

Milner, H. V. (1997b). Interests, institutions, and information: Domestic politics and international relations. Princeton, NJ: Princeton University Press.

Milner, H. V. (2006). Why multilateralism? Foreign aid and domestic principal-agent problems. In D. G. Hawkins, D. A. Lake, D. L. Nielson \& M. J. Tierney (Eds.), Delegation and agency in international organizations. New York: Cambridge University Press. 
Moravcsik, A. (1997). Taking preferences seriously: a liberal theory of international politics. International Organization, 51, 513-553.

Mundell, R. A. (1957). International trade and factor mobility. American Economic Review, 47, 321-335.

Peltzman, S. (1976). Towards a more general theory of regulation. Journal of Law and Economics, 19, 211-240.

Phillips, N. (2009). The slow death of pluralism. Review of International Political Economy, 19, 85-94.

Pincus, J. J. (1975). Pressure groups and the pattern of tariffs. Journal of Political Economy, 83, 757-778.

Pinto, P. M., \& Pinto, S. M. (2008). The politics of investment: partisanship and the sectoral allocation of foreign direct investment. Economics and Politics, 20, 216-254.

Prebisch, R. (1964). Towards a new trade policy for development. New York: United Nations.

Putnam, R. D. (1988). Diplomacy and domestic politics: the logic of two-level games. International Organization, 42, 427-460.

Ramseyer, J. M., \& McCall Rosenbluth, F. (1993). Japan's political marketplace. Cambridge, MA: Harvard University Press.

Richards, J. (1999). Toward a positive theory of international institutions: regulating international aviation markets. International Organization, 53, 1-37.

Rodrik, D. (1997). Has globalization gone too far?. Washington, DC: Institute for International Economics.

Rogowski, R. (1987). Trade and the variety of democratic institutions. International Organization, 41, 203-223.

Rogowski, R. (1989). Commerce and coalitions: How trade affects domestic political alignments. Princeton, NJ: Princeton University Press.

Rogowski, R. (1996). How economies-of-scale trade affects domestic politics. Manuscript. Los Angeles, CA: University of California, Los Angeles.

Rogowski, R. (1999). Institutions as constraints on strategic choice. In D. A. Lake \& R. Powell (Eds.), Strategic choice and international relations. Princeton, NJ: Princeton University Press.

Ruggie, J. G. (1983). International regimes, transactions, and change: Embedded liberalism in the postwar economic order. In S. D. Krasner (Ed.), International regimes. Ithaca, NY: Cornell University Press.

Sandler, T. (1997). Global challenges: an approach to environmental, political, and economic problems. New York: Cambridge University Press.

Schattschneider, E. E. (1935). Politics, pressures, and the tariff. New York: Prentice-Hall.

Scheve, K., \& Stasavage, D. (2006). Religion and preferences for social insurance. Quarterly Journal of Political Science, 1, 255-286.

Stigler, G. J. (1971). The theory of economic regulation. Bell Journal of Economic and Management Science, 2, 3-21.

Stiglitz, J. E. (2002). Globalization and its discontents. New York: W. W. Norton.

Stolper, W., \& Samuelson, P. A. (1941). Protection and real wages. Review of Economic Studies, 9, 58-73.

Stone, R. W. (2002). Lending credibility: The international monetary fund and the post-communist transition. Princeton, NJ: Princeton University Press.

Sunkel, O. (1969). National development policy and external dependence in Latin America. Journal of Development Studies, 6, 23-48.

Tomz, M. (2007). Reputation and international cooperation: Sovereign debt across three centuries. Princeton, NJ: Princeton University Press.

Triffin, R. (1960). Gold and the dollar crisis. New Haven, CT: Yale University Press.

Tsebelis, G. (2002). Veto players: How political institutions work. Princeton, NJ: Princeton.

Wade, R. (2009). Beware what you wish for: lessons for international political economy from the transformation of economics. Review of International Political Economy, 16, 106-121.

Weaver, C. (2009). IPE's split brain. New Political Economy. forthcoming.

Zysman, J., \& D'Andrea Tyson, L. (Eds). (1983). American industry in international competition: Government policies and corporate strategies. Ithaca, NY: Cornell University Press. 